\title{
POLA KEARIFAN MASYARAKAT LOKAL DALAM SISTEM SAWAH SURJAN UNTUK KONSERVASI EKOSISTEM PERTANIAN
}

\author{
Tien Aminatun, Sri Harti Widyastuti, Djuwanto \\ FMIPA Universitas Negeri Yogyakarta \\ email: tienaminatun@gmail.com
}

\begin{abstract}
Abstrak: Pola Kearifan Masyarakat Lokal dalam Sistem Sawah Surjan untuk Konservasi Ekosistem Pertanian. Tujuan penelitian ini adalah untuk mengetahui pola kearifan petani sawah surjan dalam mengkonservasi lahan pertanian dan hubungan pola kearifan petani sawah surjan dengan komponenkomponen ekosistem pertanian yang dapat dikonservasi. Metode penelitian yang digunakan adalah kuantitatif. Pengumpulan data dilakukan dengan menggunakan data sekunder dan angket. Data dianalisis secara deskriptif kuantitatif. Hasil penelitian dapat disimpulkan bahwa pola kearifan petani sawah surjan dalam mengkonservasi lahan pertanian adalah secara turun temurun, seringkali tanpa memahami makna atau tanpa sadar; dan hubungan pola kearifan petani sawah surjan dengan komponen-komponen ekosistem pertanian yang dapat dikonservasi adalah membantu menciptakan ekosistem pertanian yang lebih stabil dengan adanya keragaman tanaman yang ditanam, sehingga tidak mudah terserang hama dan dengan adanya diversifikasi hasil panen dapat memberikan keuntungan lebih bagi petani
\end{abstract}

Kata kunci: Pola kearifan masyarakat lokal, sawah surjan, konservasi

\begin{abstract}
The Local Wisdom Pattern in Surjan Farming System for Agricultural Ecosystem Conservation. This research aimed to investigate the local wisdom pattern of the farmers in conserving their farmlands; and the correlation between the local wisdom pattern of the farmers and conserved agricultural ecosystem components. This study used quantitative method. Data collected by using secondary data and questionnaire. Data were analyzed by quantitative descriptive analysis. The results were the local wisdom pattern of "surjan" farmers in conserving their farmlands was occured in cultural heritage, that sometime they did not realized it; and the correlation between the local wisdom of surjan farmers and the conserved components of agricultural ecosystem was the local wisdom supported the stability of ecosystem with its higher biodiversity which was caused more resistant to pests attact, and the farmers could get more benefit.
\end{abstract}

Keywords: The local wisdom pattern, surjan farming, conservation

\section{PENDAHULUAN}

Sawah surjan merupakan sistem pengelolaan sawah khas petani di pesisir Kulon Progo yang merupakan kearifan lokal sebagai bentuk adaptasi terhadap kondisi drainase yang buruk. Kondisi drainase yang buruk ini disebabkan karena wilayah tersebut secara geomorfologi adalah dataran fluviomarin yang merupakan bekas rawa belakang (back swamp) (Marwasta dan Priyono, 2007). Sebutan sawah surjan berasal dari morfologi sawah yang jika dilihat dari atas tampak bergaris-garis seperti baju surjan yang biasa dipakai oleh orang Jawa tempo dulu. Garis-garis tersebut terbentuk dari alur-alur tinggi yang bersifat terestrial berselang-seling dengan alur-alur rendah 
yang bersifat akuatik. Bagian yang terestrial oleh petani ditanami tanaman palawija, sedangkan bagian yang bersifat akuatik ditanami padi sepanjang tahun. Hal inilah yang menyebabkan ekosistem sawah surjan berbeda dengan sawah lembaran pada umumnya yang hanya bersifat akuatik saja.

Sawah sebagai ekosistem buatan terdiri atas komponen abiotik, biotik, dan sosialbudaya-ekonomi. Selain kondisi klimatik, komponen abiotik yang mempengaruhi produktivitas suatu ekosistem sawah adalah kondisi edafik dan hidrologik. Sistem pengairan yang berbeda antara sawah surjan dan lembaran memungkinkan perbedaan faktor edafik dan hidrologik. Hasil penelitian sebelumnya yang telah dilakukan oleh Aminatun (2012) menyatakan bahwa tidak ada perbedaan kondisi mikroklimatik (suhu udara, kelembaban udara, dan intensitas cahaya) yang berarti antara sawah surjan dan lembaran, sedangkan hasil perbandingan faktor edafik antara sawah surjan dan lembaran menunjukkan bahwa di antara parameter Kapasitas Tukar Kation (KTK), bahan organik, $\mathrm{N}$ total, $\mathrm{P}$ tersedia, $\mathrm{K}$ tersedia, $\mathrm{Ca}, \mathrm{Mg}, \mathrm{pH}$, kejenuhan basa, $\mathrm{Na}$, dan salinitas, yang menunjukkan perbedaan signifikan adalah kandungan $\mathrm{P}$ tersedia, $\mathrm{Ca}, \mathrm{pH}$ dan salinitas, yang semuanya menunjukkan bahwa kandungan $\mathrm{P}$ tersedia, $\mathrm{Ca}, \mathrm{pH}$ dan salinitas pada sawah surjan lebih tinggi daripada sawah lembaran. Akan tetapi, hasil penelitian tersebut tidak hanya terfokus pada perbedaan antara sawah surjan dan lembaran, tetapi juga pada perbedaan cara budidaya pada sawah surjan maupun lembaran, yaitu cara organik dan konvensional (ada aplikasi bahanbahan kimia anorganik), yang menunjukkan bahwa sawah surjan dengan cara budidaya organik mempunyai sifat-sfat kesuburan tanah yang lebih baik.

Hasil penelitian Aminatun (2012) tersebut juga mendapatkan data aspek hidrologi dari sawah surjan dan lembaran yang dilihat dari parameter kedalaman genangan dan kondisi kimiawi air sawah, yang menunjukkan bahwa rata-rata kedalaman genangan pada sawah surjan lebih tinggi daripada sawah lembaran, sedangkan kondisi kimiawi air sawah lebih dipengaruhi oleh cara budidaya, yaitu dengan cara organik atau konvensional, selain tergantung juga pada sumber air irigasinya.

Untuk aspek biotik pada penelitian Aminatun(2012) tersebuttelahdidapatkan hasil bahwa populasi OPT (Organisme Pengganggu Tanaman) yang berupa gulma dan serangga hama menunjukkan bahwa populasi gulma pada sawah surjan lebih tinggi daripada sawah lembaran, tetapi populasi serangga hama pada sawah surjan secara signifikan lebih rendah daripada sawah lembaran, sedangkan untuk populasi musuh alami tidak menunjukkan perbedaan yang signifikan antara sawah surjan dan lembaran. Untuk kekayaan jenis (richness) dari guma dan serangga hama pada sawah surjan secara signifikan lebih tinggi daripada sawah lembaran, sedangkan untuk kekayaan jenis (richness) dari musuh alami antara sawah surjan dan lembaran tidak menunjukkan perbedaan yang berarti. Richness yang tinggi menunjukkan keanekaragaman hayati (biodiversitas) yang lebih tinggi. Odum (1998) menyatakan bahwa ekosistem yang memiliki biodiversitas tinggi berlangsung lebih stabil dan lebih tahan terhadap guncangan yang terjadi.

Pola tanam polikultur yang diterapkan oleh petani sawah surjan dapat memberikan keuntungan, antara lain pemanfaatan sumberdaya yang lebih efisien dan lestari, karena hasil tanaman yang lebih banyak bervariasi dan dapat dipanen berturutan (Beets, 1982). Pola tanam polikultur juga memberikan keuntungan, jika sampai terjadi kegagalan panen pada salah satu tanaman budidaya, misalnya padi, maka petani masih dapat mendapatkan hasil dari tanaman yang lain, misalnya palawija. Sistem surjan 
memungkinkan panen bisa dilakukan sepanjang tahun karena pola tanam yang campuran (mixed cropping) pada bagian alur yang terestrial (guludan). Karena ekosistem sawah merupakan ekosistem buatan maka komponen sosial-ekonomi memegangperan penting dalam konservasi lahan pertanian oleh petani. Sistem pengelolaan sawah yang menghasilkan income paling tinggilah yang akan dipilih petani untuk mempertahankan atau melestarikan lahan sawahnya. Oleh karena itulah penelitian tentang 'pola kearifan masyarakat lokal dalam sistem sawah surjan untuk konservasi ekosistem pertanian' perlu untuk diteliti, sehingga permasalahan dalam penelitian ini adalah: (1) bagaimanakah pola kearifan lokal petani sawah surjan di Kulon Progo dalam mengkonservasi lahan pertanian?; (2) bagaimanakah hubungan pola kearifan petani sawah surjan di Kulon Progo dengan komponen-komponen ekosistem pertanian yang dapat dikonservasi?

\section{METODE}

Lokasi penelitian adalah di Desa Pleret, Kecamatan Panjatan, Kabupaten Kulon Progo. Lokasi ini dipilih karena mempunyai kekhasan, yaitu merupakan daerah pertanian di wilayah pesisir dengan kondisi drainase lahan yang buruk. Di lokasi ini banyak terdapat sawah surjan yang merupakan bentuk adaptasi petani secara turun-temurun terhadap kondisi drainase yang buruk tersebut.

Variabel dalam penelitian ini adalah pola kearifan petani sawah surjan dan komponen ekosistem sawah yang terdiri atas komponen abiotik, biotik dan sosial ekonomi petani. Pola kearifan petani sawah surjan dilihat dari aspek pengetahuan dan sikap petani sawah surjan terhadap sawah surjan yang dimilikinya. Komponen ekosistem abiotik terdiri atas faktor edafik atau kesuburan tanah yang dilihat dari parameter Kapasitas Pertukaran Kation (KTK), kandungan bahan organik tanah, kandungan $\mathrm{N}$ total, $\mathrm{P}$ tersedia dan $\mathrm{K}$ tersedia dalam tanah; dan faktor hidrologik yang dilihat dari parameter kedalaman genangan air sawah, sedangkan komponen biotik ekosistem dilihat dari parameter keragaman hayati, populasi hama dan musuh alaminya, serta pola interaksi yang terjadi di antara tanaman dan serangga herbivora, serta antara serangga hama dan musuh alaminya.

Instrumen Penelitian yang digunakan adalah angket wawancara kepada petani responden, yang meliputi petani sawah surjan, petani sawah lembaran, dan petani yang menggarap sawah surjan maupun lembaran. Instrumen lainnya adalah data sekunder untuk aspek abiotik dan biotik dari penelitian terdahulu (Aminatun, 2012). Analisis data dilakukan secara deskriptif kuantitatif untuk mengetahui pola kearifan petani sistem surjan dalam mengkonservasi ekosistem pertanian.

\section{HASIL DAN PEMBAHASAN}

\section{Hasil Analisis Data Sekunder Komponen Ekosistem}

Dari hasil analisis data sekunder yang berupa perbandingan kondisi komponen abiotik dan biotik antara ekosistem sawah surjan dan sawah lembaran, yang didapatkan dari hasil penelitian Aminatun (2012) adalah sebagai berikut.

\section{Kondisi Komponen Edafik}

Kondisi komponen edafik dalam penelitian ini dilihat dari indikator kesuburan tanah, yang dilihat dari sifat Kapasitas Tukar Kation (KTK), Bahan Organik (BO), Nitrogen (N) Total, Posfor (P) Tersedia, dan Kalium (K) Tersedia, yang disajikan pada Tabel 1.

KTK menjadi indikator kesuburan tanah karena KTK sangat terkait dengan sifat koloid tanah. Koloid tanah yang terdiri dari koloid organik (humus) dan anorganik (liat atau lempung dan mineral), merupakan tempat terjadinya reaksireaksi dan perubahan-perubahan yang 
Jurnal Penelitian Humaniora, Vol. 19, No.1, April 2014: 65-76

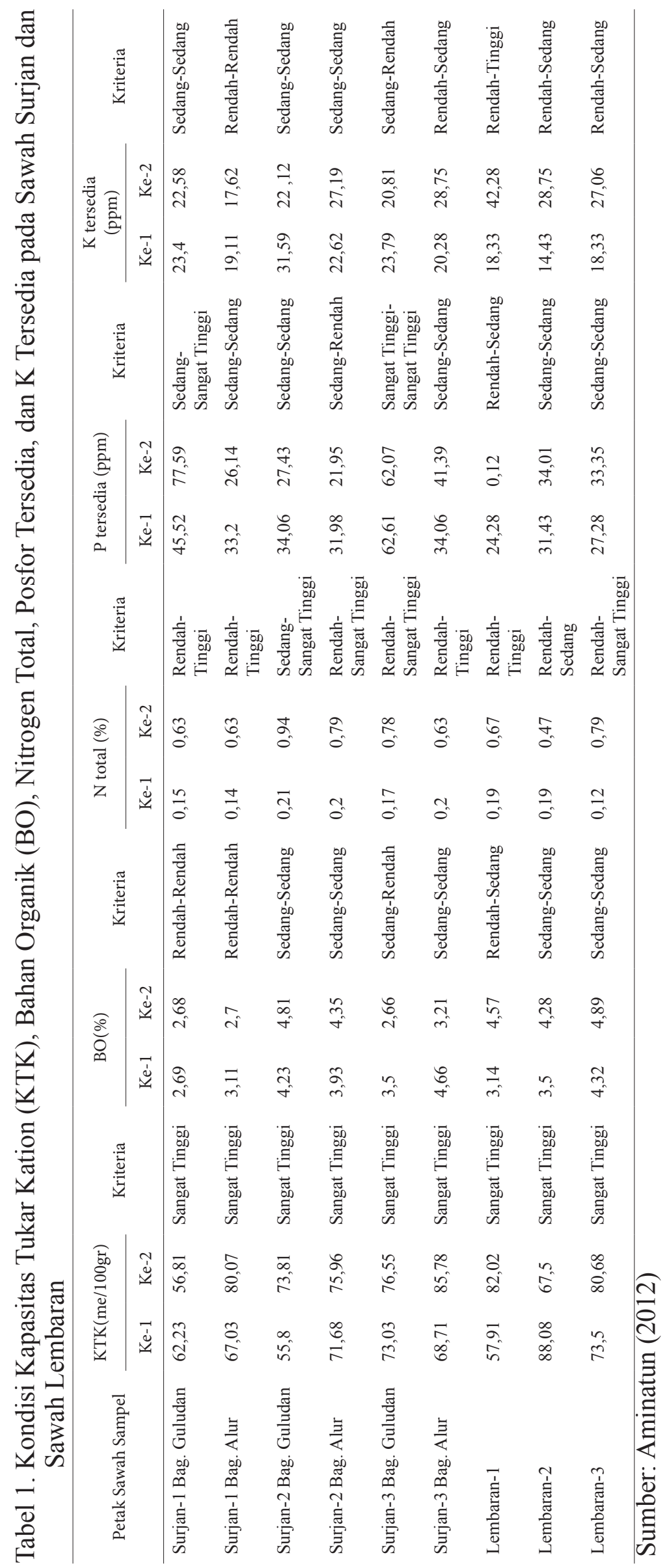


berperan langsung maupun tidak langsung dalam menyediakan unsur hara bagi tanaman. KTK merupakan kemampuan koloid tanah menjerap/mengadsorbsi dan mempertukarkan kation. KTK ini dipengaruhi oleh reaksi tanah ( $\mathrm{pH})$, tekstur tanah dan jumlah lempung, jenis mineral lempung, bahan organik, pengapuran dan pemupukan (Hakim, et al., 1986).

Bahan organik juga menjadi indikator kesuburan tanah, yang menggambarkan akumulasi residu hasil pelapukan dan pembusukan tanaman dan hewan oleh mikroorganisme tanah. Meskipun kandungan bahan organik dalam tanah hanya $3-5 \%$ dari berat topsoil, tetapi mempengaruhi sifat tanah dan pertumbuhan tanaman (Brady, 1974). Selain itu, koloid bahan organik mempunyai daya jerap kation lebih besar daripada koloid lempung, sehingga semakin tinggi bahan organik maka KTK akan semakin tinggi, sehingga kesuburan tanah juga semakin tinggi (Hakim, et al., 1986).

Unsur nitrogen, posfor dan kalium merupakan unsur hara makro dan esensial bagi tanaman, sehingga kandungannya pada tanah menjadi indikator kesuburan. Nitrogen berpengaruh jelas dan cepat terhadap pertumbuhan tanaman. Seperti halnya nitrogen, posfor merupakan hara makro dan esensial bagi pertumbuhan tanaman, sedangkan kalium merupakan unsur hara ke-3 setelah nitrogen dan posfor (Hakim, et al., 1986).

Dari Tabel 1 diketahui bahwa KTK, Bahan Organik, $\mathrm{N}$ total, $\mathrm{P}$ tersedia, dan $\mathrm{K}$ tersedia antara sawah surjan dan lembaran tidak terdapat perbedaan yang signifikan, yang menandakan bahwa tingkat kesuburan tanah pada kedua ekosistem tersebut adalah sama. Hal ini karena tekstur tanah yang mempengaruhi sifat KTK tanah di kedua ekosistem tersebut sama, yaitu lempung, dan perlakuan pemupukan antara sawah surjan dan sawah lembaran juga rata-rata memiliki pola yang sama. Dari hasil wawancara dengan petani, baik petani sawah surjan maupun lembaran rata-rata menggunakan pupuk kandang dan kompos sebagai pupuk dasar, kemudian menggunakan pupuk urea, ZA, dan TSP untuk tahap berikutnya. Hal inilah yang menyebabkan kandungan bahan organik, N, P, dan K tanah di kedua ekosistem sawah tidak berbeda nyata.

\section{Kondisi Komponen Hidrologik}

Komponen hidrologik yang dilihat dari kedalaman genangan air sawah menunjukkan perbedaan yang berarti antara sawah surjan dan lembaran dan antara musim kemarau dan musim hujan (Tabel 2). Kedalaman sawah surjan yang diukur pada bagian alur tersebut, menunjukkan rata-rata kedalaman yang lebih besar daripada sawah lembaran, dan rata-rata kedalaman lebih besar pada musim hujan daripada musim kemarau. Berdasarkan pada hasil penelitian Aminatun (2012), perbedaan kedalaman genangan antara sawah surjan dan lembaran tersebut lebih dipengaruhi oleh kedekatan lokasi petak-petak sawah dengan sumber air atau saluran irigasi, musim (hujan atau kemarau) dan ketinggian tempat atau elevasi. Selain karena lokasi petakpetak sawah surjan lebih dekat dengan sumber saluran irigasi, kedalaman sawah surjan juga dimungkinkan karena proses pembuatan guludan pada sawah surjan. Proses pembuatan guludan, yaitu dengan mengambil tanah di bagian alur kemudian ditambahkan ke bagian guludan (tabukan) akan menyebabkan bagian alur menajdi lebih dalam daripada sawah lembaran biasa sehingga genangan air akan lebih dalam. Sistem inilah yang akan mengatur drainase, sehingga tidak akan mengalami kebanjiran di musim hujan dan kekeringan lahan di musim kemarau. 
Tabel 2. Kedalaman Genangan Air pada Sawah Surjan dan Lembaran pada Musim Hujan dan Musim Kemarau

\begin{tabular}{|c|c|c|c|c|c|c|c|c|c|c|c|c|}
\hline \multirow{3}{*}{$\begin{array}{c}\text { Petak Sawah } \\
\text { Sampel }\end{array}$} & \multicolumn{10}{|c|}{ Kedalaman di Minggu Pengamatan (CM) } & \multirow{2}{*}{\multicolumn{2}{|c|}{ Rerata }} \\
\hline & \multicolumn{2}{|c|}{$\mathrm{Ke}-1$} & \multicolumn{2}{|c|}{$\mathrm{Ke}-4$} & \multicolumn{2}{|c|}{$\mathrm{Ke}-7$} & \multicolumn{2}{|c|}{$\mathrm{Ke}-10$} & \multicolumn{2}{|c|}{ Ke-13 } & & \\
\hline & MT I & MT II & MT I & MT II & MT I & MT II & MT I & MT II & MT I & MT II & MT I & MT II \\
\hline Surjan-1 & 6,5 & 0,8 & 11,5 & 12 & 17,5 & 0,5 & 14 & 0,5 & 1 & 0 & 10,1 & 2,76 \\
\hline Surjan-2 & 4 & 3,8 & 5,5 & 14,5 & 6,3 & 2 & 9 & 0 & 1,3 & 0 & 5,22 & 4,06 \\
\hline Surjan-3 & 23 & 3,3 & 3,3 & 10,3 & 10,7 & 1,2 & 8,7 & 1,5 & 0,7 & 1,8 & 9,28 & 3,62 \\
\hline Lembaran-1 & 5,4 & 2,2 & 3,7 & 10,5 & 13,6 & 5 & 4,2 & 0 & 4 & 0 & 6,18 & 6,54 \\
\hline Lembaran-2 & 3,2 & 2,2 & 5,2 & 4,8 & 9,3 & 1,7 & 4,3 & 0 & 3,3 & 0 & 5,06 & 1,74 \\
\hline Lembaran-3 & 6 & 3,1 & 5,1 & 7,8 & 12,6 & 1,9 & 6,1 & 0 & 3,1 & 0 & 6,58 & 2,56 \\
\hline
\end{tabular}

Keterangan:

Musim Tanam 1 (MT I) pada musim hujan

Musim Tanam II (MT II) pada musim kemarau

Sumber: Aminatun, 2012

\section{Kondisi Komponen Biotik}

Dari hasil penelitan Aminatun (2012), diketahui bahwa sawah surjan memiliki keragaman hayati yang lebih beragam, dilihat dari kekayaan jenis (richness) tanaman budidaya maupun gulma, serangga hama maupun musuh alaminya. Hal ini dapat dilihat dari pola interaksi yang terjadi antara tanaman (termasuk gulma) dan serangga herbivora (hama), dan interaksi antara serangga herbivora (hama) dan musuh alaminya (Gambar 1
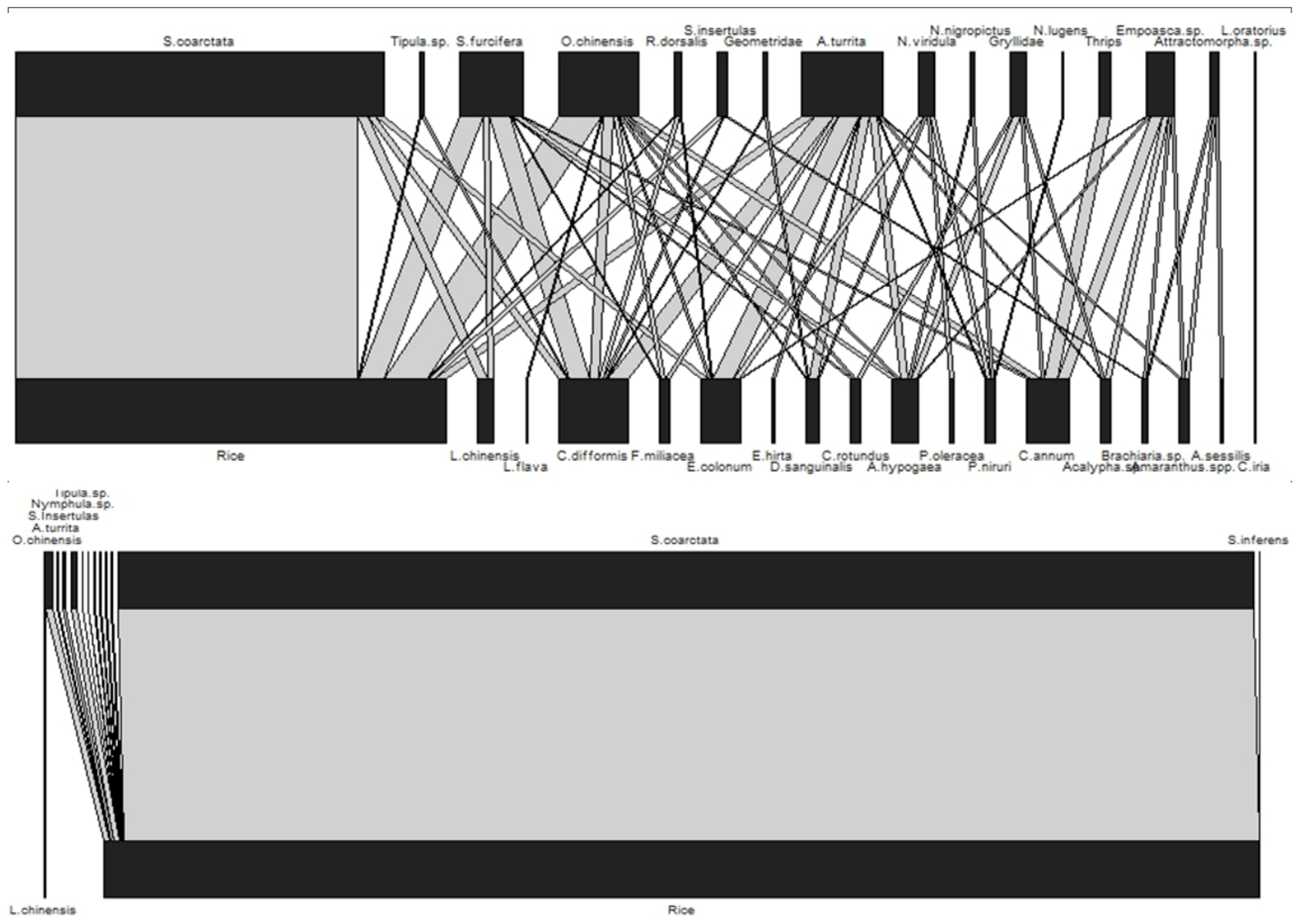

Gambar 1. Perbandingan Pola Interaksi Tanaman-Serangga Herbivora (Hama) antara Sawah Surjan (Gbr. Atas) dan Lembaran (Gbr. Bawah) (Aminatun, 2012) 
dan 2). Hal ini karena pada sawah surjan menerapkan pola tanam polikultur dengan adanya ekosistem akuatik dan terestrial, yaitu dengan menanam padi di bagian alur dan campuran beberapa jenis tanaman palawija atau sayuran pada bagian guludan. Menurut Odum (1998) pola tanam polikulturmemiliki lebihbanyak keragaman hayati sehingga ekosistem berlangsung lebih stabil. Reintjes, et al. (1999) juga menjelaskan bahwa pola tanam polikultur memberikan efek positif untuk mengurangi populasi hama, penyakit dan gulma. Musuh alami cenderung lebih banyak pada tanaman tumpangsari daripada tanaman tunggal, karena menyediakan habitat mikro dan sumber pakan yang lebih beragam.

Pada Gambar 1 tampak adanya bar atas, bar bawah dan garis interaksi antara bar atas dan bar bawah. Bar atas menggambarkan populasi jenis-jenis serangga herbivora (hama), sedangkan bar bawah menggambarkan populasi jenis-jenis tanaman. Semakin lebar bar, menunjukkan semakin tinggi populasi jenis tersebut, dan semakin lebar garis atau link interaksi menunjukkan tingginya interaksi antara bar atas (serangga hama) dan bar bawah (tanaman/gulma), yang berarti semakin tingginya intensitas serangan hama terhadap tanaman yang dikunjunginya. Dengan demikian, dari penjelasan tersebut dapat diketahui bahwa pada sawah surjan lebih banyak link interaksi yang terjadi daripada sawah lembaran, sehingga tidak tampak adanya ledakan populasi atau dominansi satu jenis hama tertentu. Sebaliknya, pada sawah lembaran tampak adanya ledakan populasi jenis hama kepinding tanah (Scotinophora sp.), yang ditunjukkan dengan lebar bar dan link interaksi antara kepinding tanah dan tanaman padi.

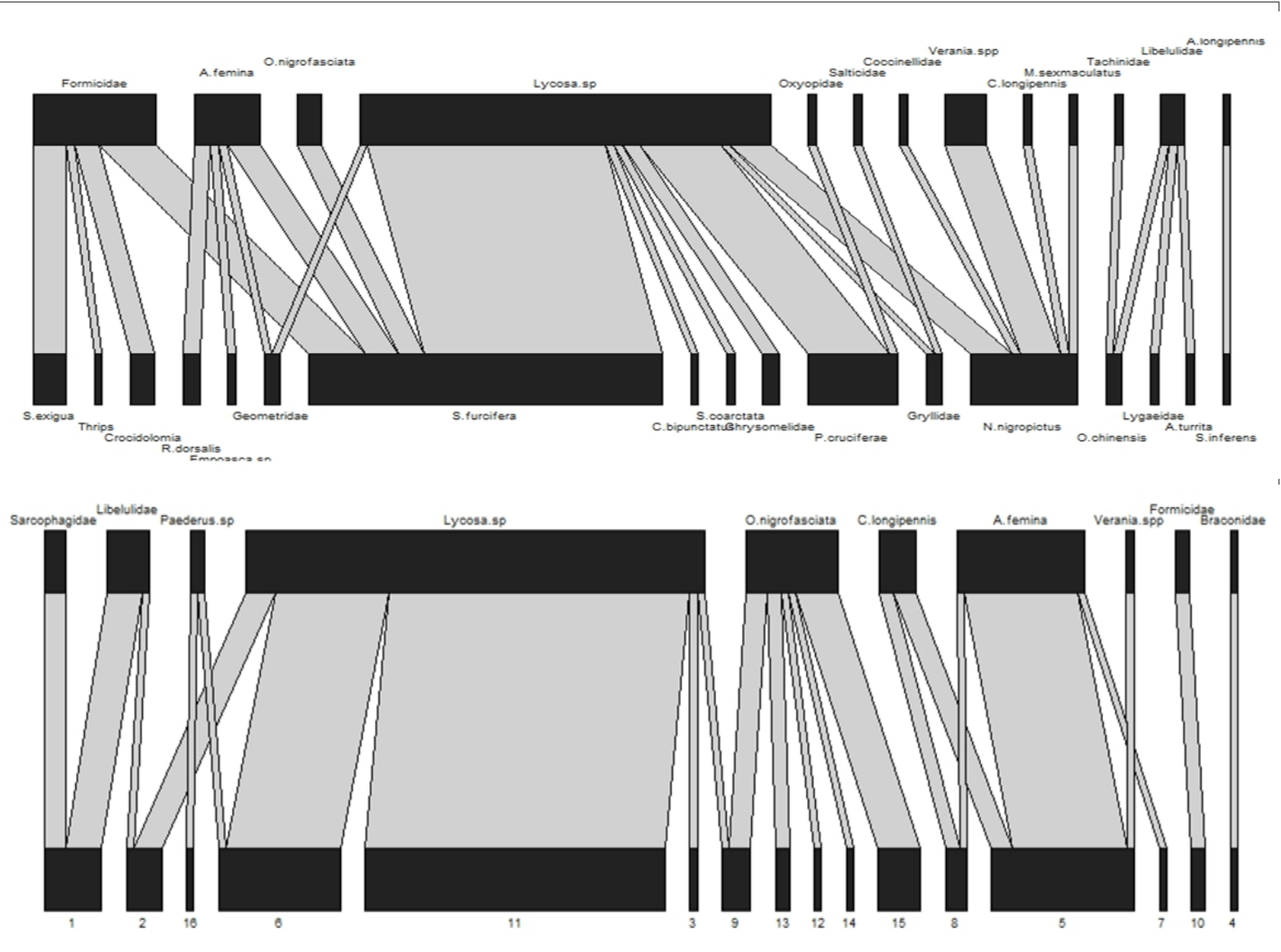

Gambar 2. Perbandingan Pola Interaksi Serangga Hama dengan Musuh Alaminya antara Sawah Surjan (Gbr. Atas) dan Lembaran (Gbr. Bawah) (Aminatun, 2012) 
Pada Gambar 2, dengan cara yang sama dengan Gambar 1, tetapi kali ini bar atas menunjukkan populasi musuh alami dan bar bawah menunjukkan populasi serangga hama, maka dapat diketahui bahwa sawah surjan cenderung memiliki pola interaksi yang lebih kompleks, dengan jumlah jenis (richness) lebih tinggi dibandingkan sawah lembaran. Jadi, pola interaksi pada sawah lembaran cenderung lebih sederhana daripada sawah surjan sehingga ekosistem mudah terkena guncangan, seperti guncangan ledakan populasi hama kepinding tanah (Scotinophora sp.) (Aminatun, 2012).

\section{Hasil Wawancara dengan Petani Responden}

Dari 60 angket yang disebarkan kepada responden, angket yang kembali dan diisi adalah 52, yang terdiri dari 15 orang petani sawah surjan, 18 orang petani yang menggarap sawah surjan maupun sawah lembaran, dan 19 orang petani sawah lembaran. Variasi umur responden dapat dilihat pada Gambar 3.

Dari Gambar 3 diketahui bahwa terjadi regenerasi petani di lokasi penelitian, yaitu dengan adanya $12 \%$ petani yang berumur di bawah 40 tahun, dan 38\% petani yang berumur antara 40-50 tahun. Hal ini mengindikasikan bahwa masih akan tetap ada pemuda desa yang mau menggarap lahan dan menjadi petani. Hal ini menjadi salah satu komponen penting dalam konservasi lahan pertanian. Selain itu, dari Gambar 4 juga diketahui bahwa terdapat 29\% petani yang berpendidikan SMA. Hal ini menunjukkan adanya peningkatan tingkat pendidikan petani. Petani yang pada

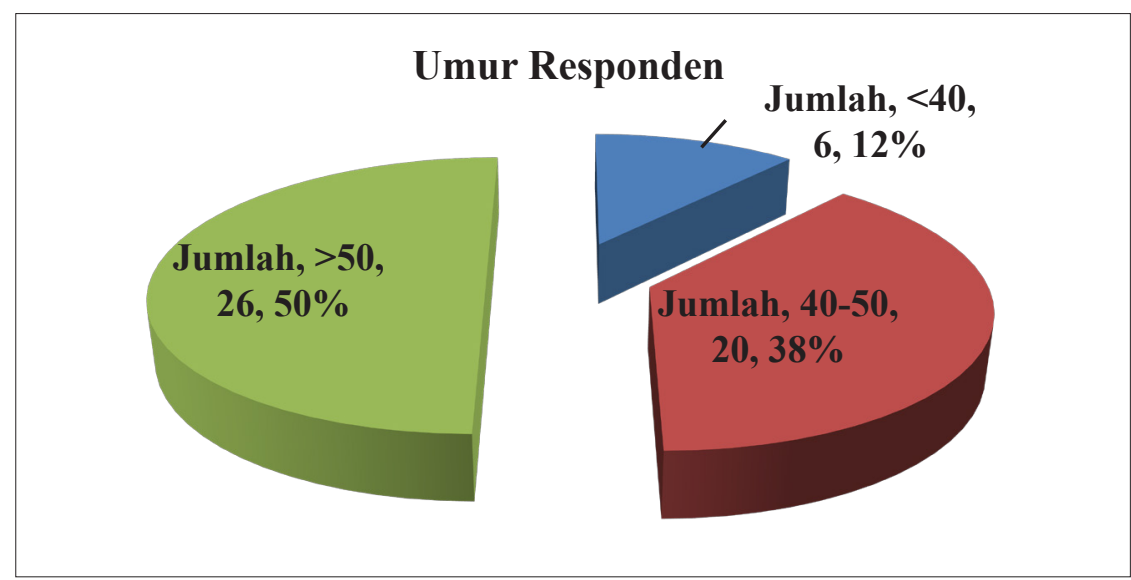

Gambar 3. Variasi Umur Petani di Daerah Penelitian

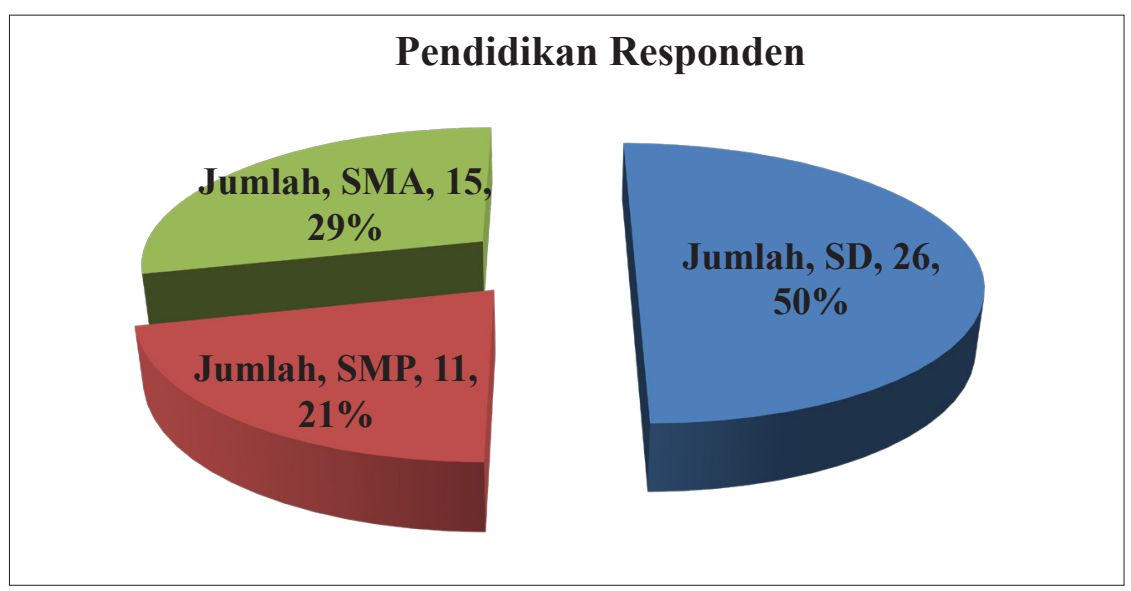

Gambar 4. Variasi Pendidikan Petani di Daerah Penelitian 
awalnya umumnya berpendidikan rendah, ternyata mulai banyak yang berpendidikan SMA. Petani yang berpendidikan lebih tinggi tersebut diharapkan mempunyai wawasan yang lebih luas. Hal ini tentunya dapat menjadi faktor pendukung bagi konservasi lahan pertanian di lokasi penelitian.

Selain ada faktor pendukung, tentu saja terdapat faktor penghambat, salah satunya adalah sebagian besar responden menjadi petani hanya sebagai sambilan, bukan pekerjaan pokok. Dari hasil wawancara, rata-rata petani tidak menjual hasil panen padinya, tetapi hanya untuk dikonsumsi sendiri. Hal ini karena untuk kebutuhan hidup sehari-hari petani mempunyai penghasilan dari sumber lain. Gambar 5 menyajikan jumlah petani yang mempunyai pekerjaan selain bertani.
Hal ini terutama akan berpengaruh pada ekosistem sawah surjan, karena sawah surjan memerlukan banyak modal tenaga untuk menggarap lahan dibandingkan dengan sawah lembaran. Pada sawah surjan, pola tanam adalah polikultur dengan tanaman padi di bagian bawah dan tanaman campuran di bagian atas (Gambar 6). Tentunya hal ini memerlukan tenaga perawatan yang lebih banyak, juga tenaga untuk pemanenan yang lebih sering dibandingkan sawah lembaran. Faktor diversifikasi produk atau hasil panen adalah merupakan faktor pendorong konservasi ekosistem sawah surjan, tetapi kebutuhan tenaga kerja yang lebih padat karya terkadang menjadi faktor penghambat konservasi sawah surjan. Contohnya, beberapa petani membiarkan

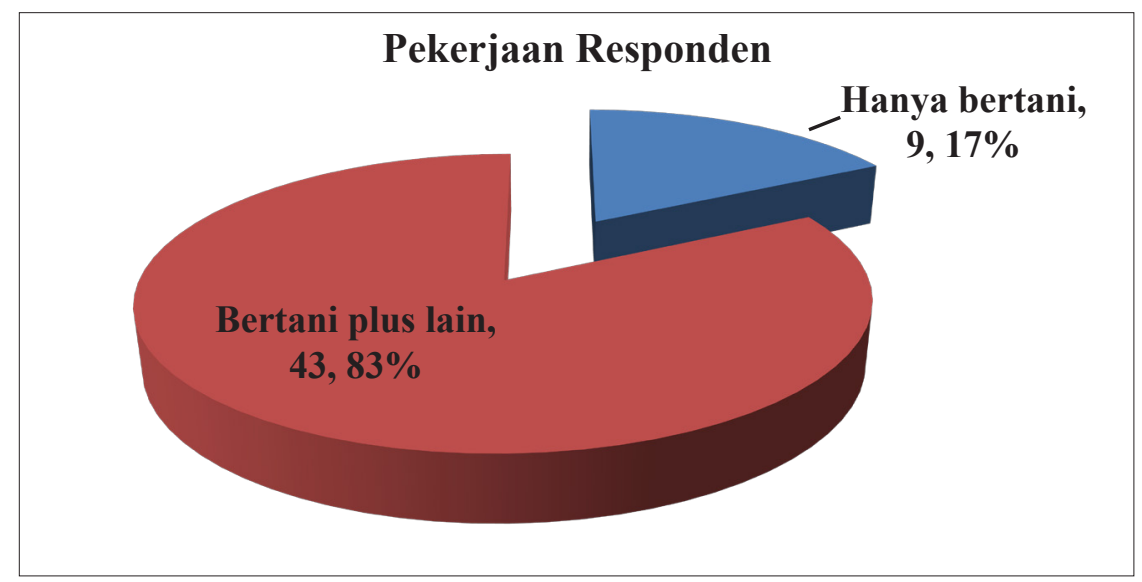

Gambar 5. Mayoritas Petani adalah Pekerjaan Sambilan

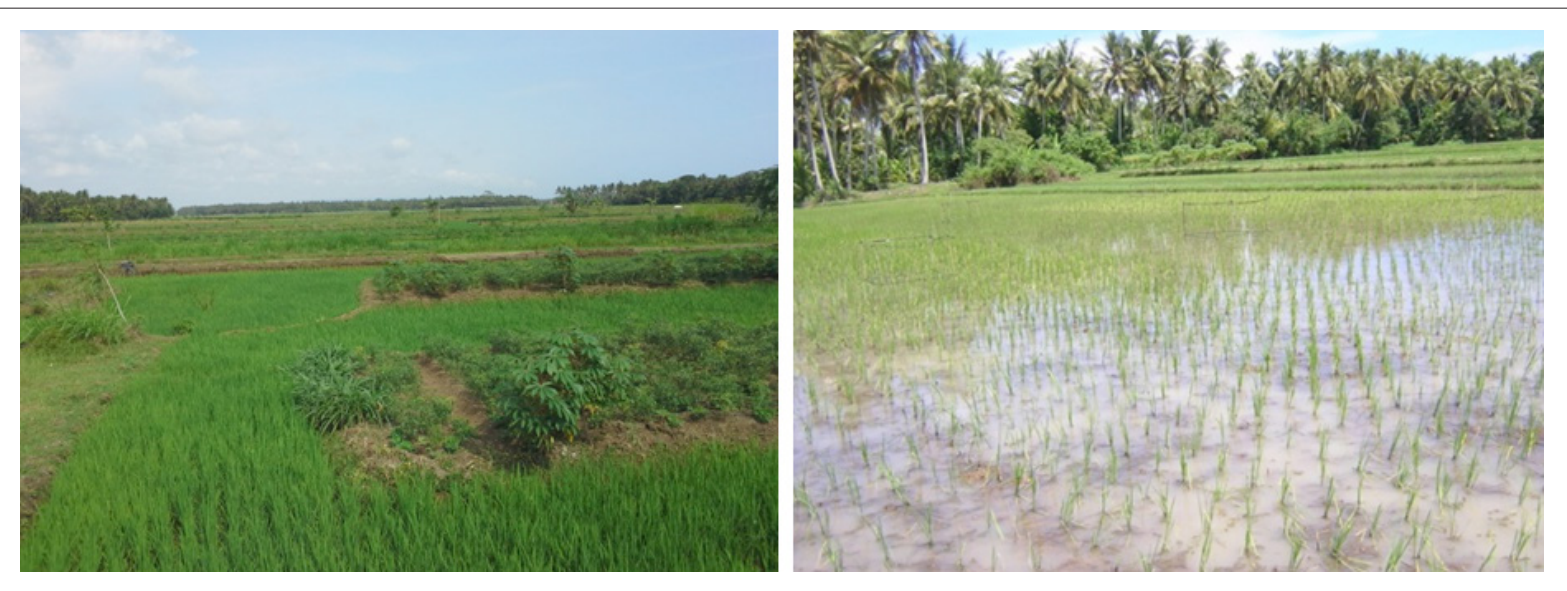

Gambar 6. Perbandingan Pola Tanam antara Sawah Surjan yang Polikultur (kiri) dan Sawah Lembaran yang Monokultur Padi (kanan) 
bagian guludan sawah surjan tidak terurus atau membiarkannya untuk tanaman rumput sebagai pakan ternak.

Dari aspek kepemilikan lahan, sebanyak $45 \%$ petani menggarap lahan sendiri tetapi juga menggarap lahan sewa, $35 \%$ yang menggarap lahan sendiri, dan sisanya menggarap lahan sewa (Gambar 7). Hal ini menunjukkan bahwa kepemilikan lahan pribadi di kalangan petani di lokasi penelitian masih cukup tinggi, dan harapannya masih akan berlanjut ke anak cucu. Dari hasl wawancara diketahui bahwa hampir semua responden ingin mewariskan lahan yang dimilikinya kepada anak cucunya untuk tetap digarap, dan pada petani sawah surjan tidak ada niat untuk mengubahnya menjadi sawah lembaran. Alasan utama mengapa tidak berniat untuk mengubah sawah surjan menjadi lembaran adalah karena dari leluhur bentuk peninggalannya sudah berupa sawah surjan, dan akan memerlukan tenaga dan biaya tinggi untuk mengubah sawah surjan menjadi sawah lembaran.

Jika disuruh memilih antara sawah surjan atau sawah lembaran, sebagian petani memilih sawah lembaran dengan alasan, dengan luas yang sama dapat panen padi lebih banyak, serta tidak perlu tenaga dan waktu yang banyak untuk mengelola bagian guludan sawah surjan. Jawaban ini terkait dengan Gambar 5 yang menyatakan bahwa mayoritas petani mempunyai pekerjaan selain bertani, sehingga mereka merasa kerepotan jika harus menyediakan tenaga dan waktu ekstra untuk mengelola bagian guludan sawah surjan terkait dengan pola tanamnya yang polikultur (Gambar 8). Tetapi, mengingat bahwa mereka dapat panen lebih banyak dan hanya sawah surjan itu yang mereka punya, maka mereka tetap mengelolanya

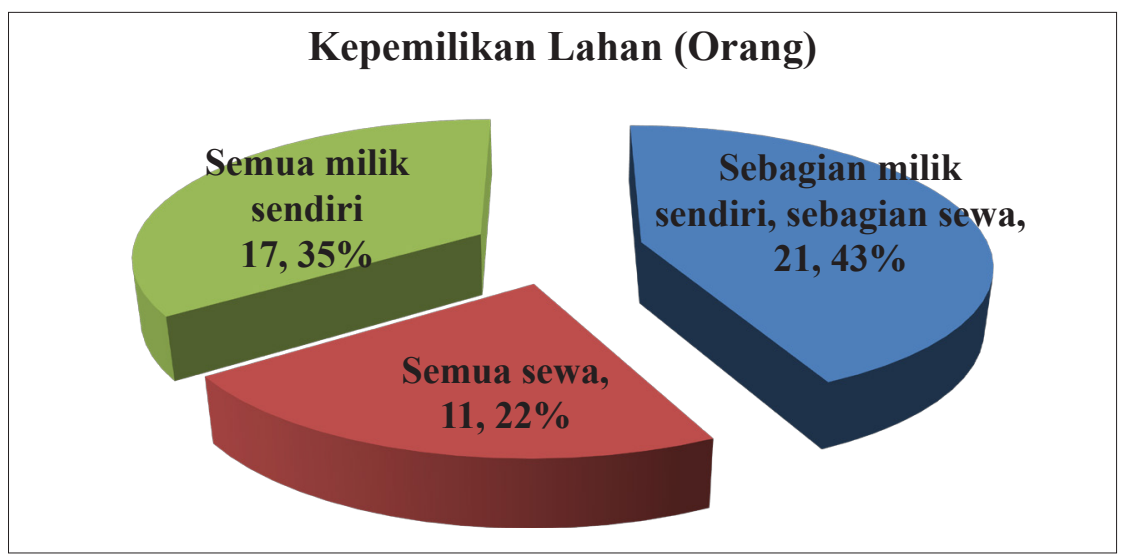

Gambar 7. Status Kepemilikan Lahan oleh Petani

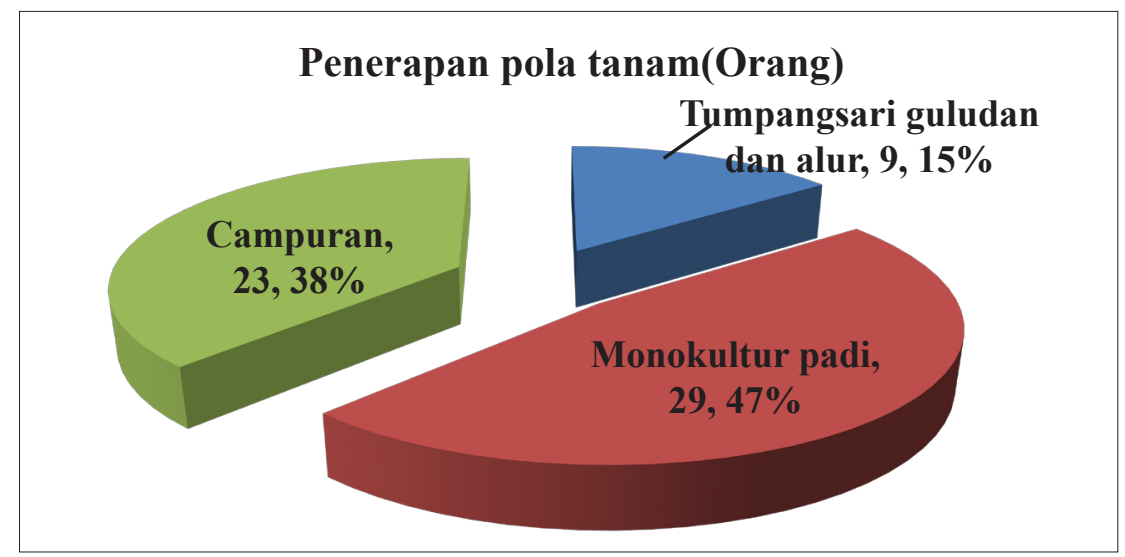

Gambar 8. Pola Tanam yang Diterapkan oleh Petani 
meski kalau disuruh memilih mereka lebih memilih sawah lembaran. Jawaban ini juga terkait dengan pengetahuan tentang sawah surjan yang mereka miliki.

Dari hasil wawancara yang disajikan pada Gambar 9, 10, dan 11, tidak semua petani mempunyai pengetahuan tentang makna sawah surjan, asal-usul sawah surjan, dan cara membuat sawah surjan, yaitu hanya $60 \%$ petani yang paham makna surjan, $48 \%$ yang tahu tentang asalusul sawah surjan, dan $79 \%$ yag tahu cara

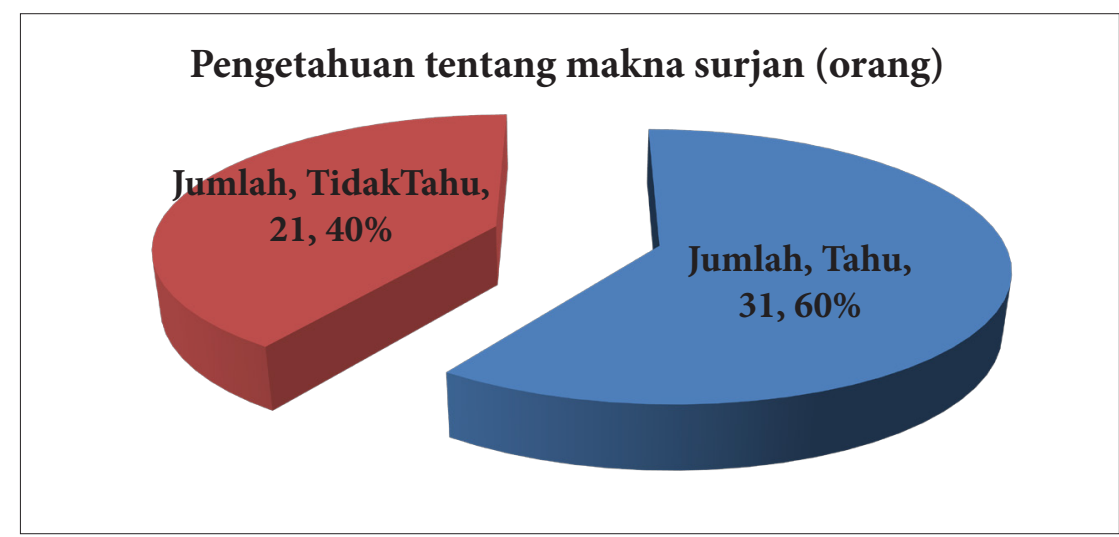

Gambar 9. Proporsi Petani yang Memahami Makna Sawah Surjan dan yang Tidak Memahami

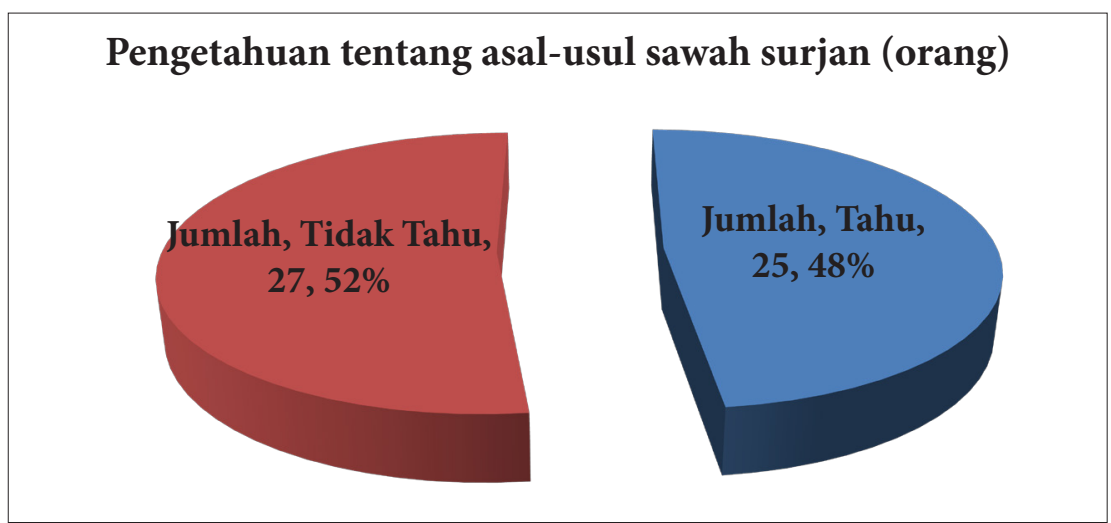

Gambar 10. Proporsi Petani yang Mengetahui Asal-Usul Sawah Surjan dan yang Tidak Mengetahui

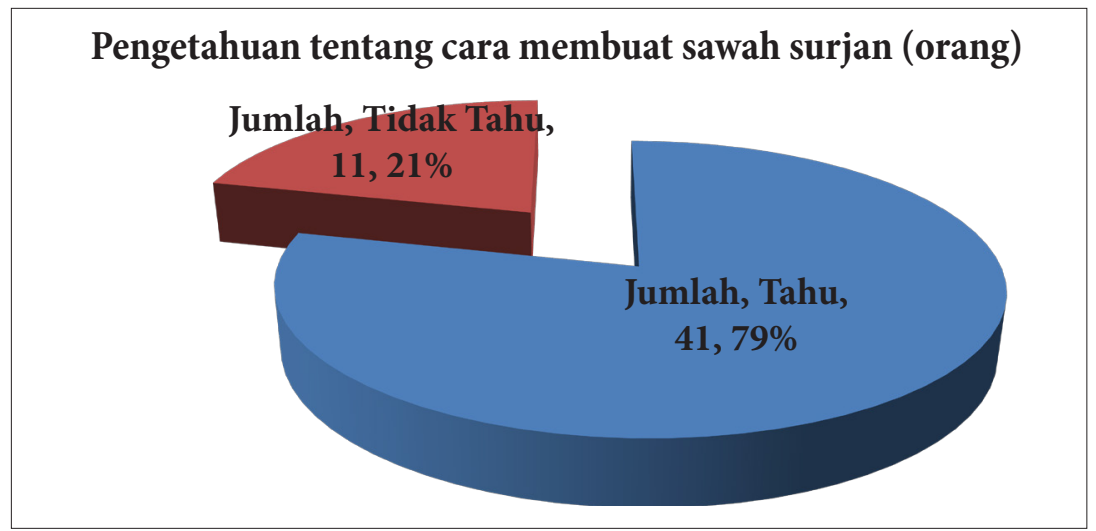

Gambar 11. Proporsi Petani yang Mengetahui Cara Membuat Sawah Surjan dan yang Tidak Mengetahui 
membuat sawah surjan. Responden yang tidak mempunyai pengetahuan tentang makna, asal-usul dan cara membuat sawah surjan menyatakan bahwa mereka hanya mendapatkan sawah surjan dari warisan dan tinggal melanjutkan tradisi nenek moyang saja.

Adanya kepemilikan sawah surjan yang turun-temurun mengindikasikan bahwa kearifan lokal yang berujud sawah surjan ini telah lestari dari generasi ke generasi, meskipun pada generasi petani saat ini pengetahuan dan makna filosofi tentang sawah surjan telah banyak yang tidak memahaminya. Mereka hanya tahu bahwa sawah surjan memberikan keuntungan lebih, yaitu dengan sawah surjan mereka tidak pernah merasakan kekeringan dan kebanjiran, dapat menanam apa saja, dan dapat sering panen dan panen apa saja (padi, sayuran, palawija, bahkan buah-buahan, seperti timun, semangka dan melon), sedangkan kekurangan sawah surjan yang mereka rasakan adalah kebutuhan modal tenaga kerja yang tinggi dibandingkan pada pengelolaan sawah lembaran.

\section{SIMPULAN}

Pola kearifan petani sawah surjan di Kulon Progo dalam mengkonservasi lahan pertanian adalah secara turun temurun, seringkali tanpa memahami makna (tanpa sadar). Hubungan pola kearifan petani sawah surjan di Kulon Progo dengan komponen-komponen ekosistem pertanian yang dapat dikonservasi adalah membantu menciptakan ekosistem pertanian yang lebih stabil dengan adanya keragaman tanaman yang ditanam, sehingga tidak mudah terserang hama dan dengan adanya diversifikasi hasil panen yang dapat memberikan keuntungan lebih bagi petani.

Temuan tersebut mengandung implikasi perlunya dilakukan penyegaran /penyuluhan kepada petani tentang pentingnya dan keistimewaan sawah surjan untuk petani-petani dengan kondisi lahan yang merupakan bekas rawa belakang pantai (kondisi drainase buruk). Disamping itu pemerintah daerah perlu berperan lebih aktif agar sawah surjan yang merupakan wujud kearifan lokal leluhur yang khas Kulon Progo lebih banyak diketahui masyarakat luas dan dapat lestari, bahkan dapat dikembangkan sebagai lokasi ekowisata pertanian.

\section{DAFTAR PUSTAKA}

Aminatun, T. 2012. Pola Interaksi SeranggaGulma pada Ekosistem Sawah Surjan dan Lembaran. Disertasi. Pasca Sarjana Universitas Gadjah Mada. Yogyakarta

Arsyad, S. 1989. Konservasi Tanah dan Air. Bogor: Penerbit IPB.

Bastaman, H. 2006. Revitalisasi Kearifan Lingkungan. Jendela Informasi dan Komunikasi. Edisi 5 Agustus 2006. Pusat Pengelolaan Lingkungan Hidup Regional Jawa. Yogyakarta

Beets, W.C. 1982. Multiple Cropping and Tropical Farming System. Hampshire: Gower Publ Co. Ltd.

Brady, N.C. 1974. The Nature and Properties of Soil. 8th Ed. New York: MacMillan Publishing Co. Inc., p: 621.

Hakim, N., Nyakpa, M.Y., Lubis, A.M., Nugroho, S.G.., Saul, M.R., Diha, M.A., Hong, G.B., dan Bailey, H.H., 1986. Dasar-dasar Ilmu Tanah. Universitas Lampung. Lampung

Marwasta, D. dan Priyono, K.D. 2007. Analisis Karakteristik Desa-desa Pesisir di Kabupaten Kulon Progo. Forum Geografi, Vol 21 No. 1, Juli 2007: 57-68

Odum, E.P. 1998. Dasar-dasar Ekologi. Edisi ke tiga (terjemahan). Yogyakarta: Gadjah Mada University Press.

Reijntjes, C., Haverkort, B. dan Bayer, A.W. 1999. Pertanian Masa Depan, Pengantar untuk Pertanian Berkelanjutan dengan Input Luar Rendah. ILEIA. Yogyakarta: Penerbit Kanisius, pp: 88-107. 